\title{
XXXIV. Sketch of a stratigraphical table, chiefly for Western Europe
}

\author{
John Young M.D.
}

To cite this article: John Young M.D. (1888) XXXIV. Sketch of a stratigraphical table, chiefly for Western Europe, Philosophical Magazine Series 5, 25:155, 274-276, DOI: $10.1080 / 14786448808628185$

To link to this article: http://dx.doi.org/10.1080/14786448808628185

册 Published online: 29 Apr 2009.

Submit your article to this journal $\lceil\pi$

Џ Article views: 2

Q View related articles $₫$ 
XXXIV. Sketch of a Stratigraphical Table, chiefly for Western Europe. By JoHN Young, M.D., Professor of Natural History and Honyman Gillespie Lecturer on Geology in Glasgow University*.

$7 \mathrm{HE}$ accompanying table is an attempt to apply and extend 1 the philosophical principle underlying a remark made many years ago by Sir A. C. Ramsay, that the Carboniferous Limestone was an episode in British Geology. I discussed the matter tentatively in 1876 (Brit. Assoc. Report, Glasgow, Address to Section C), and now submit a fuller scheme. The geology of Western Europe is the record of a border warfare between the Atlantic on the one hand and the EuropeoAsiatic continent on the other, the advance and retreat of ocean and land giving rise to a series of dissolving geographical views, not one of which can be definitely fixed. Of ocean and of continent we have little knowledge : of the debatable line between them our whole geological knowledge is made up. The index map of colours published by the Geological Survey is commonly made the basis of calculations of geological time, as if every superposed block of colour represented a distinct epoch. My table is an attempt to put in new shape the common stock of geological teachers, that land and sea are contemporaneous, and that a true narrative should not place all the strata of one region-say, Western Europe-on the top of each other, but should allow for the contemporaneous occurrence of sea and land, of thick and of thin deposits, on the inclined plane from the coast down to the floor of the adjacent sea. Sir A. C. Ramsay gave to Mr. Darwin a summary statement of British Geology, from which it seemed a fair arithmetical inference that the thickness of the sedimentary crust is 20 miles. I do not know for what purpose that statement was prepared; but I do know that it has been used by subsequent writers as if the "onioncoat theory of the earth's crust" (to use Herbert Spencer's graphic phrase) were still accepted. The right-hand side of my table is that of the permanent land-area, the left that of the permanent Atlantic Ocean. The left column shows the successive incursions of the ocean; the right column indicates the periods during which elevation carried the land, in whole or in part, to or towards the present western confines of Europe; in the interval are recorded the estuarine and fluvio-lacustrine conditions. I need not point out in detail how such a table tends to demonstrate that the duration

\section{* Communicated by the Author.}


Stratigraphical Table, chiefly for Western Europe. $\quad 275$

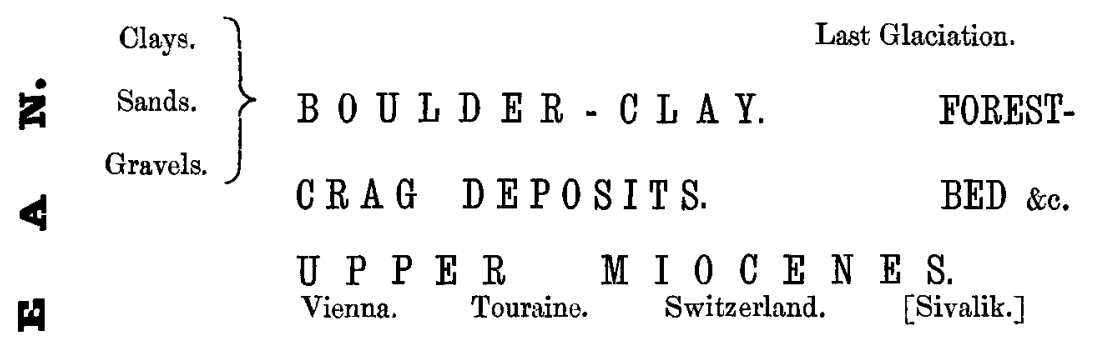

[NUMMULITIC.] ENGLISH EOCENE, LOWER MIOCENE.

- Europeo-Asiatic.

- CHALK. NEOCOMIAN. PURBECK-WEALD.

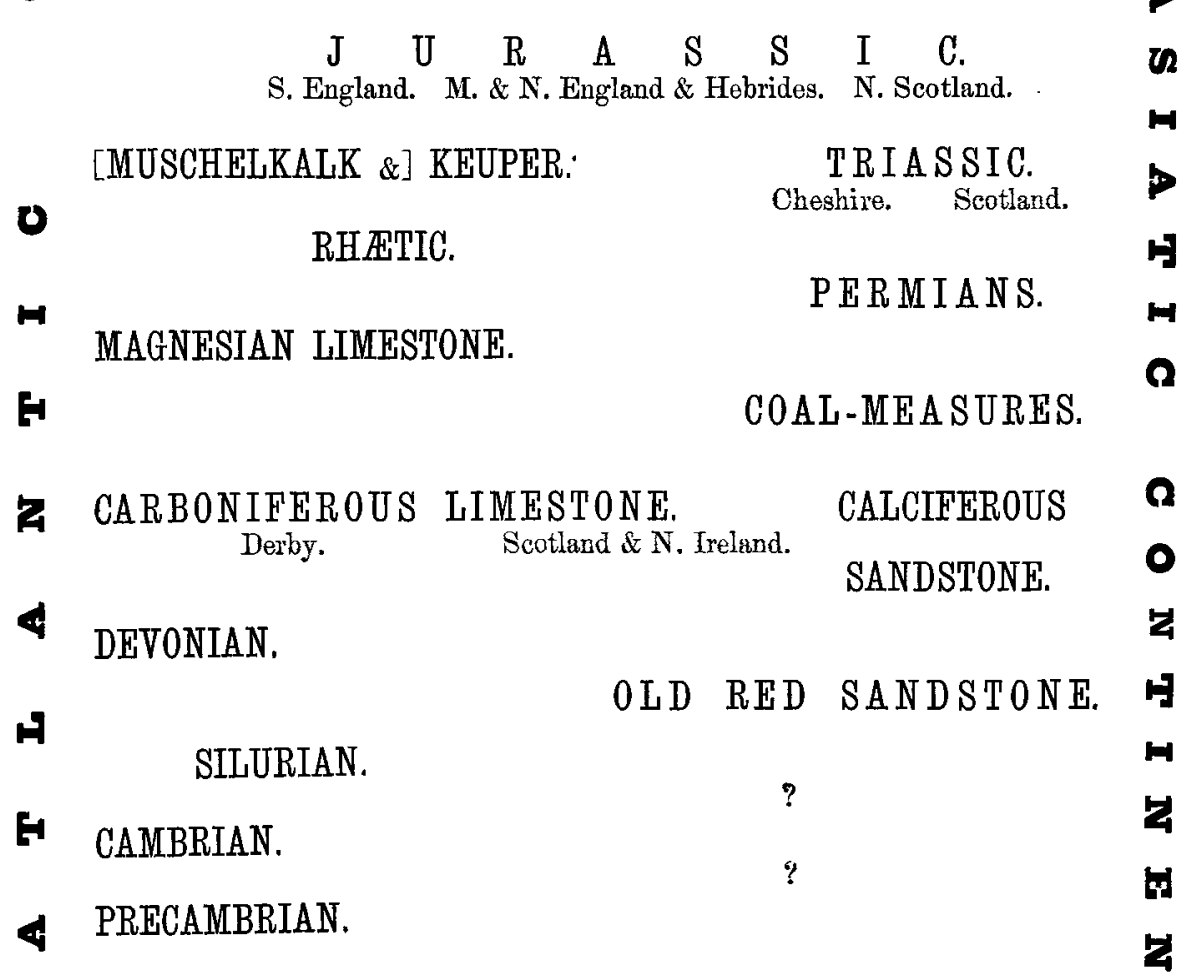

Deeper Sea. Shallow. Estuarine. Fluvio-lacustrine. Terrestrial. 
of geological time is not so great as is ordinarily assumed. There is no reason to believe that the time required for the deposit of thick strata must be longer, proportionally to the number of feet, than that required for the deposit of thin. If the thick strata had been laid down in waters as deep as the average of the deeper areas of the Atlantic, vast time might perhaps have been required; but there is no evidence for such depths having ever been attained to the east of the present line of 100 -fathom soundings off the British Islands. Even the Carboniferous and Cretaceous Limestones do not prove the existence of such deep waters; they only show that at these periods there was long-continued subsidence and continuous deposit in clear water. Prof. Huxley's homotaxis is thus applied within the compass of the European area ; and, if the views embodied in this table are correct, the careful correlation of strata which has given so much occupation to geologists loses much of its importance. The palæontological differences are the variations of inhabitants of adjacent zoological areas on a sea-floor inclining westwards.

XXXV. Experiments on Electrolysis.-Part I. Change of Density of the Electrolyte at the Electrodes. By W. W. HaLdane GEE, B.Se., Assistant Lecturer in Physics, and H. Holden, B.Sce, Bishop Berkeley Fellow in Physics, of the Owens College, Manchester**

WHILST studying some electrolytic polarization phenomena with palladium electrodes in dilute pure sulphuric acid, a liquid was seen, after a reversal of the current, to flow downwards in streaks from the anode. Not being able to find any reference to the formation of streaks, for whose appearance the reversal of the current was necessary, it was decided to investigate their character. Further, it was thought that the occluded hydrogen might, on reversal of the current, unite with the nascent ion liberated at the anode, and thus effect chemical changes of an interesting character.

Some little care in observation and adjustment of the light

* Communicated by the Physical Society : read February 25, 1888.

This is the first of a series of papers on Electrolysis and Electrolytic Polarization, descriptive of experiments made, during last year, at the Owens College Physical Laboratory. An abstract of the experiments made, to the end of August 1887, was subenited to the British Association Meeting at Manchester. We desire to acknowledge the assistance received up to that time from Mr. C. H. Lees, B.Sc., Derby Mathematical Scholar of the Owens College. His cooperation has since been discontinued, owing to absence at Strasburg. 